\title{
An identification tool for the Australian weedy Sporobolus species based on random amplified polymorphic DNA (RAPD) profiles
}

\author{
Sangita Shrestha ${ }^{\mathrm{A}, \mathrm{B}, \mathrm{E}}$, Stephen W. Adkins ${ }^{\mathrm{A}, \mathrm{E}, \mathrm{F}}$, Glenn C. Graham ${ }^{\mathrm{C}}$, \\ and Donald S. Loch ${ }^{\mathrm{D}}$ \\ ${ }^{\text {A }}$ School of Land and Food Sciences, University of Queensland, Brisbane, Qld 4072, Australia. \\ ${ }^{B}$ Royal Nepal Academy of Science and Technology (RONAST), Lalitpur, Nepal. \\ ${ }^{\mathrm{C}}$ Centre for Identification and Diagnostics (CID), University of Queensland, Brisbane, Qld 4072, Australia. \\ ${ }^{\mathrm{D}}$ Queensland Department of Primary Industries, Redland Research Station, Redland Bay, Brisbane, Qld 4156, Australia. \\ ${ }^{E}$ Tropical and Sub-Tropical Weed Research Unit, University of Queensland, Brisbane, Qld 4072, Australia. \\ ${ }^{\mathrm{F}}$ Corresponding author. Email: s.adkins@uq.edu.au
}

\begin{abstract}
Based on morphological features alone, there is considerable difficulty in identifying the 5 most economically damaging weed species of Sporobolus [viz. S. pyramidalis P. Beauv., S. natalensis (Steud.) Dur and Schinz, S. fertilis (Steud.) Clayton, S. africanus (Poir.) Robyns and Tourney, and S. jacquemontii Kunth.] found in Australia. A polymerase chain reaction (PCR)-based random amplified polymorphic DNA (RAPD) technique was used to create a series of genetic markers that could positively identify the 5 major weeds from the other less damaging weedy and native Sporobolus species. In the initial RAPD profiling experiment, using arbitrarily selected primers and involving 12 species of Sporobolus, 12 genetic markers were found that, when used in combination, could consistently identify the 5 weedy species from all others. Of these 12 markers, the most diagnostic were UBC51 490 for S. pyramidalis and S. natalensis; UBC43 $310,2000,2100$ for S. fertilis and S. africanus; and OPA20 850 and $\mathrm{UBC}_{4} 3_{470}$ for $S$. jacquemontii. Species-specific markers could be found only for $S$. jacquemontii. In an effort to understand why there was difficulty in obtaining species-specific markers for some of the weedy species, a RAPD data matrix was created using 40 RAPD products. These 40 products amplified by 6 random primers from 45 individuals belonging to 12 species, were then subjected to numerical taxonomy and multivariate system (NTSYS pc version 1.70) analysis. The RAPD similarity matrix generated from the analysis indicated that $S$. pyramidalis was genetically more similar to $S$. natalensis than to other species of the 'S. indicus complex'. Similarly, $S$. jacquemontii was more similar to $S$. pyramidalis, and S. fertilis was more similar to $S$. africanus than to other species of the complex. Sporobolus pyramidalis, S. jacquemontii, S. africanus, and S. creber exhibited a low within-species genetic diversity, whereas high genetic diversity was observed within S. natalensis, S. fertilis, S. sessilis, S. elongates, and S. laxus. Cluster analysis placed all of the introduced species (major and minor weedy species) into one major cluster, with $S$. pyramidalis and S. natalensis in one distinct subcluster and S. fertilis and S. africanus in another. The native species formed separate clusters in the phenograms. The close genetic similarity of $S$. pyramidalis to $S$. natalensis, and $S$. fertilis to $S$. africanus may explain the difficulty in obtaining RAPD species-specific markers. The importance of these results will be within the Australian dairy and beef industries and will aid in the development of integrated management strategy for these weeds.
\end{abstract}

Additional keywords: diagnostics, fingerprinting, genetic diversity, PCR, rat's tail grasses, species identification.

\section{Introduction}

Of the 24 species of the genus Sporobolus that have been reported to be present in Australia, 11 have been included in the weedy 'Sporobolus indicus complex' (Simon 1999). Five of these [viz. giant rat's tail grasses S. pyramidalis P. Beauv and $S$. natalensis (Steud.) Dur. and Schinz, giant Parramatta grass $S$. fertilis (Steud) Clayton, Parramatta grass
S. africanus (Poir.) Robyns and Tourney, and American rat's tail grass $S$. jacquemontii Kunth.] are now serious weeds (Laffan 1986; Betts et al. 1990; Anon. 1997) and 4 (viz. S. elongatus R. Br., S. creber De Nardi, S. laxus B. K. Simon, S. sessilis B. K. Simon) are less economically damaging. Of the 2 remaining members of the $S$. indicus complex [S. indicus (L.) R. Br. and S. diandrus P. Beauv], 
S. diandrus has not yet been reported in Australia, whereas a phylogenetic study (Shrestha et al. 2003) involving one suspected $S$. indicus seed sample from Victoria, has raised the possibility that this species is now present in Australia. This has yet to be confirmed.

The two giant rat's tail grasses and giant Parramatta grass constrain Australian pasture production, with their effects mainly on the dairy and beef industries. The distribution of these 3 weeds is still increasing and therefore it is estimated that they will have an even greater impact on these industries. Their main effect is on animal production as they are unpalatable and reduce the carrying capacity of the pasture. Eco-climatic modelling has suggested that the giant rat's tail grasses have the potential to establish in most areas receiving as little as $500 \mathrm{~mm}$ annual rainfall. Thus, 108 million ha of Queensland (60\% of the total land area) and 233 million ha of Australia (30\% of the total land area; Anon. 1999) may be under threat.

The past taxonomic identification of weedy (from native) Sporobolus species has been based on morphological characters alone (Simon 1993; Simon and Jacobs 1999) and has resulted in many misidentifications. This inability to clearly identify native and introduced minor weeds from the seriously weedy species has created many difficulties for the development of effective weed management strategies. Identification based on electrophoretic analysis of seed proteins, using SDS-PAGE, has been attempted (Vieritz 1993); however, due to certain limitations of this technique, it could not be developed into a reliable diagnostic protocol. In this context, nucleic-acid-based molecular marker techniques could provide reliable identification options. The polymerase chain reaction (PCR)-based random amplified polymorphic DNA (RAPD) technique (Welsh and McClelland 1990; Williams et al. 1990) has been widely used for plant species and varietal identification (Graham et al. 1994; Joel et al. 1996; Golembiewski et al. 1997). The method can also be used for inferring the nature of taxonomic relationships (Graham et al. 1996; Moodie et al. 1997; Lopez-Martinez et al. 1999) among closely related species. In the RAPD technique, molecular markers are produced following the PCR amplification of DNA fragments using randomly selected short oligonucleotide primers (usually 10 bases long) of arbitrary sequence. The polymorphic DNA fragments produced can be compared among a range of species, and suitable fragments selected to act as species identification markers. The qualitative data on presence or absence of the RAPD fragments in each species can be used to generate similarity indices (Dice 1945; Sokal and Michener 1958; Sokal and Sneath 1963) that in turn are used to reveal genetic relationships among the species.

In the present investigation, a RAPD-PCR technique was used to develop molecular markers that are useful for the identification of the 5 major Australian weedy Sporobolus species. The approach was also used to study the inter- and intra-specific variation among various species of the $S$. indicus complex with a view to understanding the genetic diversity and the interrelationship of the members of the S. indicus complex and their relationship to the Australian native species. This information can in turn be used in weed management strategy development.

\section{Materials and methods}

\section{Plant materials}

Fifty-five seed samples, belonging to 14 species of Sporobolus (11 species of the $S$. indicus complex and 3 Australian native species), were examined in this study (Table 1). Thirteen of these seed samples were collected from sites around Australia with the help of the Queensland Department of Primary Industries (QDPI) and the Queensland Department of Natural Resources and Mines (QNRM); 29 were provided by B. K. Simon, Queensland Herbarium (QH, Brisbane); 5 came from the University of New England; 5 came from unknown sources; 1 from the Maitland City Council; and 2 from landholder sites in New South Wales (NSW) and Queensland (Qld). Species identification was carried out by morphological identification undertaken on mature, reproductive plants (B. K. Simon, QH).

\section{DNA extraction}

Extraction of DNA was carried out from seed tissue (c. 10-50 mg of caryopses) using the technique of Edwards et al. (1991). In this procedure, caryopses were placed in Eppendorf tubes $(1.5 \mathrm{~mL})$, surface-sterilised $(2 \% \mathrm{v} / \mathrm{v}$ sodium hypochlorite solution for $10 \mathrm{~min})$, rinsed ( 3 or 4 times with sterile distilled water), and ground in an extraction buffer $(800 \mu \mathrm{L} ; 200 \mathrm{~mm}$ Tris- $\mathrm{HCl} \mathrm{pH} 7.5,250 \mathrm{~mm} \mathrm{NaCl}$, $25 \mathrm{~mm}$ EDTA, $0.5 \%$ SDS). Samples were well shaken and then further centrifuged (18 $890 \mathrm{~g}$ for $2 \mathrm{~min})$. Supernatant aliquots $(600 \mu \mathrm{L})$ were transferred to fresh Eppendorf tubes and combined with isopropanol $(600 \mu \mathrm{L})$. Following further centrifugation $(18890 \mathrm{~g}$ for $5 \mathrm{~min})$ the supernatants were carefully discarded and pellets dried overnight at $4{ }^{\circ} \mathrm{C}$ in the fridge. The pellets were then dissolved in TE buffer (Tris EDTA buffer, $50-300 \mu \mathrm{L}$, depending upon the size of the pellet; $10 \mathrm{~mm}$ Tris $\mathrm{HCl} \mathrm{pH} 8.0$ and $1 \mathrm{~mm}$ EDTA $\mathrm{pH} 8.0$ ) and stored at $4 \pm 1^{\circ} \mathrm{C}$. Estimation of the amount of DNA extracted from the various seed samples was carried out using a spectrophotometric method (GeneQuant II, RNA/DNA calculator, Amersham Pharmacia, Biotech, Australia).

\section{Generation of RAPD markers for species identification}

In preliminary trials, an optimised RAPD-PCR reaction and cycling condition was identified. In a final reaction volume $(25 \mu \mathrm{L})$, the optimised RAPD-PCR reaction mixture consisted of genomic DNA $(25 \mathrm{ng}), \mathrm{MgCl}_{2}(2.5 \mathrm{~mm})$, reaction buffer $(2.5 \mu \mathrm{L} ; 670 \mathrm{~mm}$ Tris- $\mathrm{HCl} \mathrm{pH} 8.8$ at $25^{\circ} \mathrm{C}, 166 \mathrm{~mm}\left(\mathrm{NH}_{4}\right)_{2} \mathrm{SO}_{4}, 4.5 \%$ Triton $\mathrm{X}-100$, $2 \mathrm{mg} / \mathrm{mL}$ Gelatin), dNTPs $(0.2 \mathrm{~mm})$, Taq polymerase (1.1 units), and a decanucleotide primer $(0.4 \mu \mathrm{M})$. The primers selected were obtained from 2 sources (OPA primer set, Operon Technologies, Alameda, USA, and a UBC primer set, University of British Columbia, Oligonucleotide Synthesis Laboratory, Vancouver, British Columbia, Canada). The optimised RAPD-PCR program consisted of 1 cycle of $1 \mathrm{~min}$ at $94^{\circ} \mathrm{C}$, 35 cycles of $10 \mathrm{~s}$ at $94^{\circ} \mathrm{C}, 30 \mathrm{~s}$ at $38^{\circ} \mathrm{C}$, and $60 \mathrm{~s}$ at $72^{\circ} \mathrm{C}$, followed by 5 min extension at $72^{\circ} \mathrm{C}$. Initially, 120 decamer primers (20 from the OPA set, and 100 from the UBC set) were screened against genomic DNA of $S$. pyramidalis. From this, 49 primers giving banding profiles with Sporobolus DNA were chosen and used in a RAPD-PCR profiling experiment involving 9 species (6 from the $S$. indicus complex and 3 natives). Deoxyribonucleic acid was extracted from seed of the 9 species and tested with each of the 49 primers in an attempt to 
Table 1. Sporobolus seed samples used in the RAPD investigation showing status, place and date of collection, and source

QDPI, Queensland Department of Primary Industries; QNRM, Queensland Department of Natural Resources and Mines; QH, Queensland Herbarium; UNE, University of New England, Armidale; MCC, Maitland City Council, NSW; -, unknown

\begin{tabular}{|c|c|c|c|c|}
\hline $\begin{array}{l}\text { Sporobolus species, } \\
\text { status }\end{array}$ & $\begin{array}{l}\text { Sample ID/ } \\
\text { abbreviation }\end{array}$ & Place of collection & Date of collection & Source \\
\hline \multirow{5}{*}{$\begin{array}{l}\text { S. pyramidalis } \\
\quad \text { (introduced serious } \\
\text { weed) }\end{array}$} & $1 / \mathrm{sp} 1$ & Gympie, Qld & 1995 & D. S. Loch, QDPI \\
\hline & $22 / \mathrm{sp} 22$ & Mackay, Qld & - & - \\
\hline & $48 / \mathrm{sp} 48$ & Fox Tail Flats, Qld & $22 / 4 / 1999$ & W. Vogler, QNRM \\
\hline & 49/sp49 & Gympie, Qld & $6 / 4 / 1999$ & W. Vogler, QNRM \\
\hline & $55 / \mathrm{sp} 55$ & Kilcoy, Qld & $15 / 1 / 1997$ & W. Vogler, QNRM \\
\hline \multirow{4}{*}{$\begin{array}{l}\text { S. jacquemontii } \\
\quad \text { (introduced minor } \\
\text { weed) }\end{array}$} & $87 / \mathrm{sj} 87$ & Mareeba, Qld & 1991 AQ381528 & B. K. Simon, QH \\
\hline & $114 / \mathrm{sj} 114$ & Fox Tail Flats, Qld & $4 / 1999$ & M.Yee, QDPI \\
\hline & $116 / \mathrm{sj} 116$ & Gyndah, Qld & - & S. Bray, QDPI \\
\hline & $135 / \mathrm{sj} 135$ & North Kennedy, Qld & 8/6/1995 AQ638698 & B. K. Simon, QH \\
\hline \multirow{7}{*}{$\begin{array}{l}\text { S. fertilis } \\
\quad \text { (introduced serious } \\
\quad \text { weed) }\end{array}$} & $25 / \mathrm{sf} 25$ & Toolara, Qld & $25 / 11 / 1998$ & - \\
\hline & $140 / \mathrm{sf} 140$ & Wide Bay, Qld & 9/5/1994 AQ627161 & B. K. Simon, QH \\
\hline & $36 / \mathrm{sf} 36$ & Grafton, NSW & $4 / 3 / 1999$ & R. D. B. Whally, UNE \\
\hline & $45 / \mathrm{sf} 45$ & Wollombi, NSW & $11 / 3 / 1999$ & B. Warby, MCC \\
\hline & $84 / \mathrm{sf} 84$ & Morton, Qld & 21/1/1997 AQ660362 & B. K. Simon, QH \\
\hline & $92 / \mathrm{sf} 92$ & Nambucca, NSW & $21 / 1 / 1997$ & B. K. Simon, QH \\
\hline & $17 / \mathrm{sf17}$ & Nambucca, NSW & $17 / 2 / 1999$ & - \\
\hline \multirow{4}{*}{$\begin{array}{l}\text { S. africanus } \\
\text { (introduced minor } \\
\text { weed) }\end{array}$} & $12 / \mathrm{sa} 12$ & Gympie, Qld & 2/11/1998 & - \\
\hline & $5 / \mathrm{sa} 5$ & Unknown, NSW & - & R. D. B. Whally, UNE \\
\hline & $125 / \mathrm{sa} 125$ & Taree, NSW & - & - \\
\hline & $143 /$ sa143 & Perth, WA & $5 / 11 / 1995$ & B. K. Simon, QH \\
\hline \multirow{2}{*}{$\begin{array}{l}\text { S. indicus (supposed } \\
\text { not in Australia) }\end{array}$} & 138/si138 & Horsham, Vic. & 3/1994 AQ626781 & B. K. Simon, QH \\
\hline & $160 /$ si160 & Unknown, Mexico & 8/1991 AQ520220 & B. K. Simon, QH \\
\hline \multirow{7}{*}{$\begin{array}{l}\text { S. natalensis } \\
\quad \text { (introduced serious } \\
\text { weed) }\end{array}$} & $151 / \mathrm{sn} 151$ & Chatsworth, Qld & 11/5/1995 AQ636832 & B. K. Simon, QH \\
\hline & $152 / \mathrm{sn} 152$ & Wide Bay, Qld & 3/1/1990 AQ459339 & B. K. Simon, QH \\
\hline & $153 / \mathrm{sn} 153$ & Wide Bay, Qld & 4/1995 AQ635642 & B. K. Simon, QH \\
\hline & $83 / \mathrm{sn} 83$ & Port Curtis, Qld & 11/1993 AQ622016 & B. K. Simon, QH \\
\hline & $110 / \operatorname{sn} 110$ & Gympie, Qld & $3 / 1999$ & P. Jones, QDPI \\
\hline & $157 / \mathrm{sn} 157$ & Blouberg, South Africa & 1991 AQ517699 & B. K. Simon, QH \\
\hline & $159 / \operatorname{sn} 159$ & Pretoria, South Africa & 20/2/1992 AQ532340 & B. K. Simon, QH \\
\hline \multirow{4}{*}{$\begin{array}{l}\text { S. sessilis } \\
\quad \text { (native) }\end{array}$} & $126 /$ ss 126 & Wide Bay, Qld & 1/11/1995 AQ488451 & B. K. Simon, QH \\
\hline & $128 / \mathrm{ss} 128$ & Unknown, PNG & $24 / 4 / 1991$ & B. K. Simon, QH \\
\hline & $129 /$ ss 129 & Yogyakarta, Indonesia & 11/9/1992 AQ547041 & B. K. Simon, QH \\
\hline & $130 /$ ss 130 & Port Curtis, Qld & 1/2/1993 AQ564757 & B. K. Simon, QH \\
\hline \multirow{3}{*}{$\begin{array}{l}\text { S. diandrus } \\
\quad \text { (supposed not } \\
\text { in Australia) }\end{array}$} & $154 / \mathrm{sd} 154$ & Java, Indonesia & 4/9/1992 AQ547035 & B. K. Simon, QH \\
\hline & $155 / \operatorname{sd} 155$ & Java, Indonesia & 9/9/1992 AQ 547019 & B. K. Simon, QH \\
\hline & $156 / \operatorname{sd} 156$ & Kuala Lumpur, Malaysia & 11/1992 AQ563368 & B. K. Simon, QH \\
\hline \multirow{3}{*}{$\begin{array}{l}\text { S. elongatus } \\
\text { (endemic) }\end{array}$} & $91 / \mathrm{se} 91$ & Wide Bay, Qld & 5/7/1996 AQ489955 & B. K. Simon, QH \\
\hline & $41 / \mathrm{se} 41$ & Talarm, NSW & $2 / 4 / 1992$ & R. D. B. Whally, UNE \\
\hline & $73 / \mathrm{se} 73$ & Gyndah, Qld & $4 / 1999$ & S. Bray, QDPI \\
\hline \multirow{3}{*}{$\begin{array}{l}\text { S. creber } \\
\text { (endemic) }\end{array}$} & $10 / \operatorname{scr} 10$ & Chatsworth, NSW & $11 / 1998$ & D. Flower - \\
\hline & $11 /$ scr11 & Bular, Kikivan, Qld & $11 / 1998$ & J. Clery - \\
\hline & $37 / \operatorname{scr} 37$ & Armidale, NSW & $7 / 3 / 1999$ & R. D. B. Whally, UNE \\
\hline \multirow{2}{*}{$\begin{array}{l}\text { S. laxus } \\
\text { (endemic) }\end{array}$} & $88 / \mathrm{s} 188$ & Bundaberg, Qld & 15/11/1996 AQ572692 & B. K. Simon, QH \\
\hline & $90 / \mathrm{s} 190$ & Mt Bartle Frere, Qld & 17/11/1996 AQ657711 & B. K. Simon, QH \\
\hline \multirow{4}{*}{$\begin{array}{l}\text { S. carolii } \\
\quad \text { (endemic) }\end{array}$} & $42 / \mathrm{sca} 42$ & Mallawa area, NSW & $8 / 2 / 1999$ & R. D. B. Whally, UNE \\
\hline & $76 /$ sca76 & Ban ban Station, Qld & $4 / 1999$ & S. Bray, QDPI \\
\hline & $104 /$ sca104 & Glentulloch, Qld & $31 / 3 / 1999$ & D. S. Loch, QDPI \\
\hline & $105 /$ sca105 & Roma, Qld & $30 / 3 / 1999$ & D. S. Loch, QDPI \\
\hline \multirow{4}{*}{$\begin{array}{l}\text { S. australasicus } \\
\text { (endemic) }\end{array}$} & $95 /$ sau95 & Gregory North, Qld & 30/4/1994 AQ632322 & B. K. Simon, QH \\
\hline & 107/sau107 & Keilambiti, Qld & $9 / 4 / 1999$ & P. Jones, QDPI \\
\hline & $146 /$ sau 146 & South Kennedy, Qld & 12/8/1997 AQ661416 & B. K. Simon, QH \\
\hline & 147 sau 147 & Camooweal, Qld & 28/4/1995 AQ587010 & B. K. Simon, QH \\
\hline \multirow{3}{*}{$\begin{array}{l}\text { S. actinocladus } \\
\text { (endemic) }\end{array}$} & 94/sac94 & Derby, WA & 29/3/1996 AQ532951 & B. K. Simon, QH \\
\hline & 106/sac106 & Roma, Qld & $30 / 3 / 1999$ & D. S. Loch, QDPI \\
\hline & $148 /$ sac148 & Perth, WA & 4/4/1995 AQ598102 & B. K. Simon, QH \\
\hline
\end{tabular}


find weedy species-specific polymorphic markers. Twelve primers, revealing high degrees of polymorphisms between weedy and native species, were chosen for further study in a marker confirmation experiment. In this experiment, 52 (out of the original 55) seed samples from 14 species (11 from the $S$. indicus complex and 3 Australian natives) were used. In all cases, the RAPD-PCR products were analysed on a $1.5 \%(\mathrm{w} / \mathrm{v})$ agarose gel in TBE buffer (Tris borate EDTA buffer, $1 \times)$ and visualised after staining in ethidium bromide for $45 \mathrm{~min}$ and de-staining for $10 \mathrm{~min}$ in water and photographed using a Polaroid camera system.

\section{Study of genetic diversity and relationship}

Gel photographs (taken from the marker confirmation experiment described above) for 6 randomly selected primers were scored for the presence or absence of RAPD fragments across 45 selected native and weedy species samples and a data matrix created. The matrix was analysed using a numerical taxonomy and multivariate system (NTSYS-pc, Version 1.70; Exeter Software, Setauket, New York). Similarity indices were calculated using a similarity for qualitative data (SIMQUAL) computer algorithm. From these similarity indices, sequential, agglomerative, hierarchical, and nested (SAHN) clustering was performed using the unweighted pair group method of arithmetic averages algorithm (UPGMA; Sneath and Sokal 1973). From this, phenograms were developed to show the relationships among members of different species. Estimates of similarity were based on the following 3 different measures.

(1) Simple matching coefficient (SM) (Sokal and Michener 1958):

$$
\mathrm{S} i j=a+d / a+b+c+d
$$

(2) Dice's coefficient of similarity (Dice 1945; Nei and Li 1979):

$$
\mathrm{S} i j=2 a / 2 a+b+c
$$

(3) Jaccard's coefficient (Jaccard 1908):

$$
\mathrm{S} i j=a / a+b+c
$$

where $\mathrm{S} i j$ is the similarity between 2 individuals, $i$ and $j$; $a$ is the number of bands present in both $i$ and $j ; b$ is the number of bands present in $i$ and absent in $j ; c$ is the number of bands present in $j$ and absent in $i$; and $d$ is the number of bands absent from both $i$ and $j$.

\section{Results}

Identification of weedy species-specific RAPD markers

Of the 120 decamer primers used in the initial primer screening using genomic DNA of $S$. pyramidalis, only 49 primers were selected to be used in the RAPD profiling experiment and, of these 49 primers, only 24 produced scorable bands. From these 24 primers, 174 bands were amplified in the 3 major weedy species ( $S$. pyramidalis, $S$. jacquemontii, and $S$. fertilis) included in the experiment. Of these, $116(67 \%)$ were polymorphic and $58(33 \%)$ were monomorphic (Table not shown; Shrestha 2001).

From the RAPD profiling experiment (Table 2), 26 polymorphic RAPD bands were revealed that could be useful in identifying the various weedy Sporobolus species. When these markers were re-examined in a marker

Table 2. The 26 weedy species-specific RAPD markers observed after using various primers in

\begin{tabular}{|c|c|c|c|}
\hline $\begin{array}{l}\text { Primer } \\
\text { code }\end{array}$ & $\begin{array}{l}\text { Primer sequence } \\
5^{\prime} \text { to } 3^{\prime}\end{array}$ & Weedy Sporobolus spp. & $\begin{array}{l}\text { Marker size } \\
\text { (base pairs) }\end{array}$ \\
\hline OPA05 & AGGGGTCTTG & S. pyramidalis & 320 \\
\hline OPA20 & GTTGCGATTC & S. pyramidalis, S. jacquemontii, S. fertilis & 900 \\
\hline OPA20 & GTTGCGATTC & S. jacquemontii & 850 \\
\hline UBC05 & CCTGGGTTCC & S. pyramidalis, $S$. jacquemontii & 1210 \\
\hline UBC12 & CCTGGGTCCA & S. fertilis & 1600 \\
\hline UBC12 & CCTGGGTCCA & S. pyramidalis, $S$. jacquemontii & 1200 \\
\hline UBC13 & CCTGGGTGGA & S. pyramidalis, $S$. jacquemontii, S. fertilis & 520 \\
\hline $\mathrm{UBC} 13$ & CCTGGGTGGA & S. pyramidalis, S. jacquemontii, S. fertilis & 1000 \\
\hline UBC13 & CCTGGGTGGA & S. pyramidalis, S. jacquemontii, S. fertilis & 2000 \\
\hline UBC43 & AAAACCGGGC & S. fertilis & 310 \\
\hline UBC43 & AAAACCGGGC & S. pyramidalis & 600 \\
\hline UBC43 & AAAACCGGGC & S. pyramidalis, $S$. jacquemontii, S. fertilis & 650 \\
\hline UBC43 & AAAACCGGGC & S. fertilis & 2100 \\
\hline UBC43 & AAAACCGGGC & S. fertilis & 2200 \\
\hline UBC51 & CTACCCGTGC & S. pyramidalis, $S$. jacquemontii & 490 \\
\hline UBC51 & CTACCCGTGC & S. pyramidalis, S. jacquemontii, S. fertilis & 950 \\
\hline UBC52 & TTCCCGGAGC & S. fertilis & 660 \\
\hline UBC58 & TTCCCGGAGC & S. fertilis & 650 \\
\hline UBC59 & TTCCGGGTGC & S. pyramidalis, S. jacquemontii, S. fertilis & 590 \\
\hline UBC59 & TTCCGGGTGC & S. pyramidalis, $S$. jacquemontii & 1400 \\
\hline UBC61 & TTCCCCGACC & S. pyramidalis, $S$. jacquemontii & 850 \\
\hline UBC61 & TTCCCCGACC & S. fertilis & 240 \\
\hline UBC75 & GAGGTCCAGA & S. pyramidalis, $S$. jacquemontii & 510 \\
\hline UBC75 & GAGGTCCAGA & S. pyramidalis, $S$. jacquemontii, S. fertilis & 950 \\
\hline UBC92 & CCTGGGCTTT & S. fertilis & 950 \\
\hline UBC92 & CCTGGGCTTT & S. pyramidalis, $S$. jacquemontii & 1030 \\
\hline
\end{tabular}
a RAPD profiling experiment

The size of the various markers involved is also indicated 
Table 3. Potential use of various markers in the identification of 5 major weedy species

+ , Markers always useful for identification; $+/-$, markers sometimes useful, seen with some individuals but not in all

\begin{tabular}{|c|c|c|c|c|c|c|}
\hline \multirow[t]{2}{*}{ Primer } & \multirow{2}{*}{$\begin{array}{c}\text { Fragment size } \\
\text { (base pairs) }\end{array}$} & \multicolumn{5}{|c|}{ Sporobolus spp. (and sample no.) } \\
\hline & & $\begin{array}{c}\text { pyramidalis } \\
\text { (5) }\end{array}$ & $\begin{array}{c}\text { jacquemontii } \\
\text { (4) }\end{array}$ & $\begin{array}{l}\text { natalensis } \\
\text { (5) }\end{array}$ & $\begin{array}{l}\text { fertilis } \\
\text { (4) }\end{array}$ & $\begin{array}{l}\text { africanus } \\
\text { (4) }\end{array}$ \\
\hline OPA20 & 850 & - & $+{ }^{\mathrm{A}}$ & - & - & - \\
\hline OPA20 & 900 & + & + & + & + & - \\
\hline UBC13 & 2000 & + & - & $+1-$ & $+1-$ & $+1-$ \\
\hline UBC43 & 310 & - & - & - & $+^{\mathrm{A}}$ & $+^{\mathrm{A}}$ \\
\hline UBC43 & 470 & - & $+^{\mathrm{A}}$ & - & - & - \\
\hline UBC43 & 650 & + & - & + & $+1-$ & $+1-$ \\
\hline UBC43 & 2100 & - & - & - & $+{ }^{\mathrm{A}}$ & $+^{\mathrm{A}}$ \\
\hline UBC43 & 2000 & - & - & - & $+{ }^{\mathrm{A}}$ & $+{ }^{\mathrm{A}}$ \\
\hline UBC51 & 490 & $+{ }^{\mathrm{A}}$ & - & $+{ }^{\mathrm{A}}$ & - & - \\
\hline UBC75 & 950 & + & + & + & $+/-$ & - \\
\hline UBC92 & 930 & - & - & $+1-$ & + & $+1-$ \\
\hline UBC92 & 1000 & + & - & $+1-$ & + & $+1-$ \\
\hline
\end{tabular}

${ }^{A}$ Various weedy species-specific markers.

confirmation experiment involving 49 seed samples coming from all 12 Sporobolus species, 12 bands were revealed to be the most useful in separating the various weedy species (Table 3). The important RAPD-PCR markers observed were $\mathrm{UBC} 51_{490}$ for $S$. pyramidalis and $S$. natalensis, $\mathrm{UBC}_{4} 3_{310}, \mathrm{UBC}_{4} 3_{2100}$, and $\mathrm{UBC}_{4} 3_{2000}$ for $S$. fertilis and $S$. africanus, and $\mathrm{UBC}_{4} 3_{470}$ and $\mathrm{OPA} 20_{850}$ for S. jacquemontii (Figs 1, 2, 3, 4, and 5). More importantly, the DNA fingerprint profile generated by a single primer UBC43 can positively identify 5 major weedy Sporobolus species of Australia (Figs 1 and 2).

\section{Genetic diversity and relationship based on RAPD data}

The RAPD similarity matrix generated by the NTSYS pc program revealed the degree of inter- and intra-specific genetic diversity among various Sporobolus species under study. Inter-species genetic diversity ranged from 10 to $76 \%$ in pair wise comparisons between the various species of the weedy $S$. indicus complex. The highest genetic diversity $(76 \%)$ was revealed between the $S$. sessilis sample obtained from Papua New Guinea (ss 128) and a Queensland sample of $S$. fertilis (sf140). The least genetic diversity (10\%) was revealed between the $S$. creber sample of NSW (scr 37) and the $S$. elongatus sample of Qld (se73). Individuals of American rat's tail grass ( $S$. jacquemontii) and giant rat's tail grass ( $S$. pyramidalis) were $65-83 \%$ similar, whereas $S$. natalensis and $S$. pyramidalis individuals were $65-85 \%$ similar. Similarity value between $S$. fertilis and S. pyramidalis individuals ranged from 45 to $65 \%$, whereas between $S$. fertilis and $S$. natalensis they ranged from 48 to $65 \%$ (Table 4).

Giant rat's tail grass $S$. pyramidalis was found to be genetically most similar to another giant rat's tail grass, $S$. natalensis (65-85\% similar), whereas it was most genetically dissimilar to $S$. elongatus $(40-56 \%$ similar).

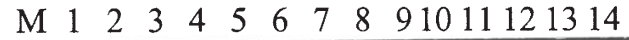

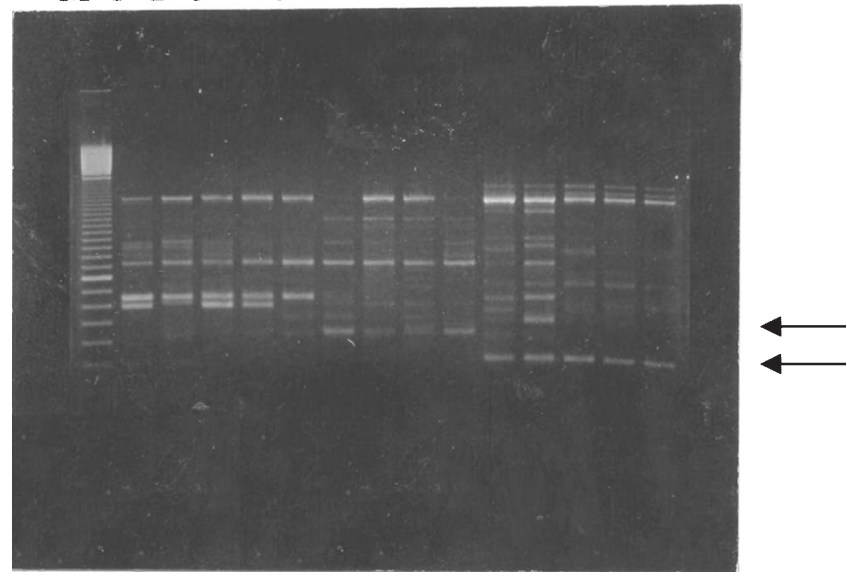

Fig. 1. RAPD profile generated by primer UBC43 with 14 samples of Sporobolus belonging to 3 species (sp, S. pyramidalis; sj, S. jacquemontii; sf, S. fertilis). Lanes marked with $\mathrm{M}$ are $100 \mathrm{bp}$ molecular weight markers and lanes 1-14 are sp1, sp22, sp48, sp49, sp55, sj87, sj114, sj116, sj135, sf25, sf140, sf36, sf45, sf120. Arrows indicate $S$. jacquemontii (470 bp) and S. fertilis (310 bp)-specific markers.

Giant rat's tail grass $S$. natalensis was most dissimilar to $S$. sessilis (47-68\% similar). American rat's tail grass $S$. jacquemontii was most similar to giant rat's tail grass S. pyramidalis $(65-83 \%$ similar) and most dissimilar to $S$. africanus (43-55\% similar). Giant Parramatta grass S. fertilis was shown to be most similar to $S$. africanus ( $70-83 \%$ similar) and most dissimilar to $S$. sessilis (24-68\% similar) (Table 4). Inter-specific genetic similarity between the species of the $S$. indicus complex and Australian natives considered in the present study (viz. S. carolii, S. actinocladus, and S. australasicus) ranged from $37 \%$ (between S. carolii and S. fertilis) to $90 \%$ (between 


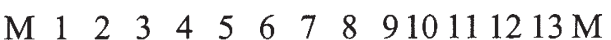

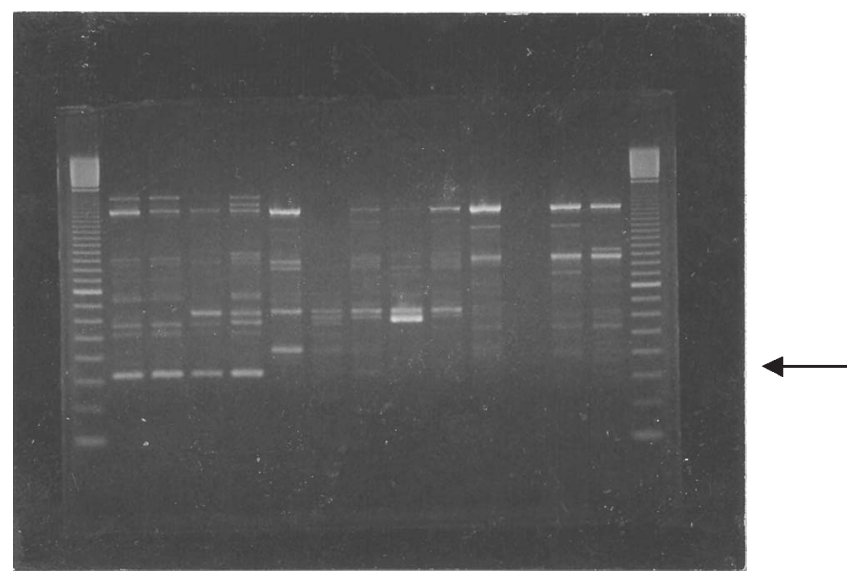

Fig. 2. RAPD profile generated by primer UBC43 with 13 samples of Sporobolus belonging to 3 species (sa, S. africanus; sn, S. natalensis; and ss, S. sessilis). Lanes marked with $\mathrm{M}$ are $100 \mathrm{bp}$ molecular weight markers and lanes 1-13 are sa12, sa5, sa125, sa143, sn151, sn152, sn153, sn83, sn110, ss126, ss128, ss129, ss130. Arrow indicates S. africanus (310 bp)-specific marker (310 bp, lanes 1-4).

\section{M $12 \begin{array}{lllllllllll} & 2 & 4 & 5 & 6 & 7 & 8 & 91011 & 1213 \mathrm{M}\end{array}$}

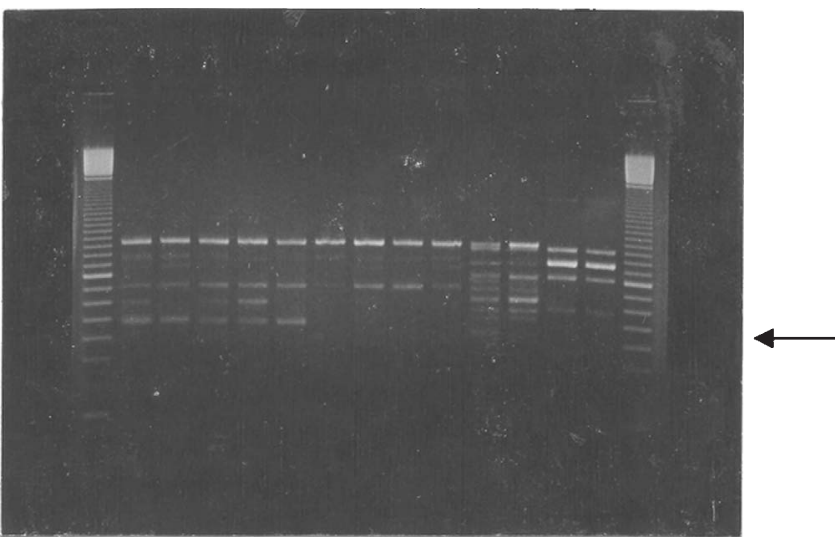

Fig. 3. RAPD profile generated by primer UBC51 with 13 samples of Sporobolus belonging to 3 species (sp, Sporobolus pyramidalis; $\mathrm{sj}$, S. jacquemontii; and sf, S. fertilis). Lanes marked with M are $100 \mathrm{bp}$ molecular weight markers and lanes 1-13 are sp1, sp22, sp48, sp49, sp55, sj87, sj114, sj116, sj135, sf25, sf140, sf36, sf45. Arrow indicates $S$. pyramidalis (490 bp)-specific marker (490 bp, lanes 1-5).

\section{S. actinocladus and $S$. elongatus) (similarity matrix} not shown).

RAPD similarity matrix showed a low genetic diversity within giant rat's tail grass (S. pyramidalis), American rat's tail grass (S. jacquemontii), Parramatta grass (S. africanus), and $S$. creber (similarity values of $90-98 \%, 93-100 \%$, $90-95 \%$, and $92-97 \%$, respectively) as compared with the other 5 species under study (viz. giant rat's tail grass $S$. natalensis and giant Parramatta grass $S$. fertilis, $S$. sessilis, $S$. elongates, and $S$. laxus; similarity values were $54-93 \%, 65-100 \%, 70-98 \%, 75-84 \%$, and $90 \%$, respectively) (Table 4).

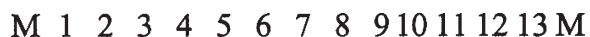

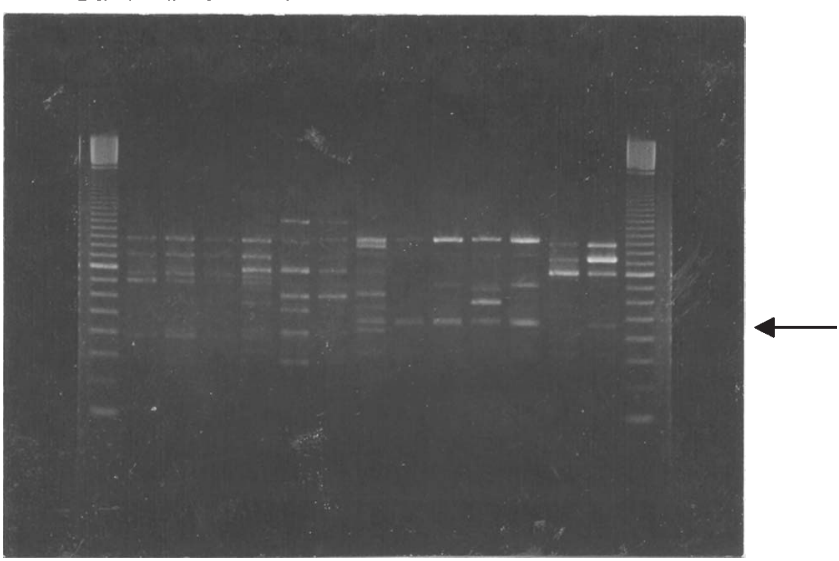

Fig. 4. RAPD profile generated by primer UBC51 with 13 samples of Sporobolus belonging to 3 species (sa, S. africanus; si, S. indicus; and sn, S. natalensis). Lanes marked with M are $100 \mathrm{bp}$ molecular weight markers and lanes 1-13 are sa12, sa5, sa125, sa143, si138, si160, sn151, sn152, sn153, sn83, sn110, sn157, sn157. Arrow indicates S. natalensis (490 bp)-specific marker (490 bp, lanes 7-11).

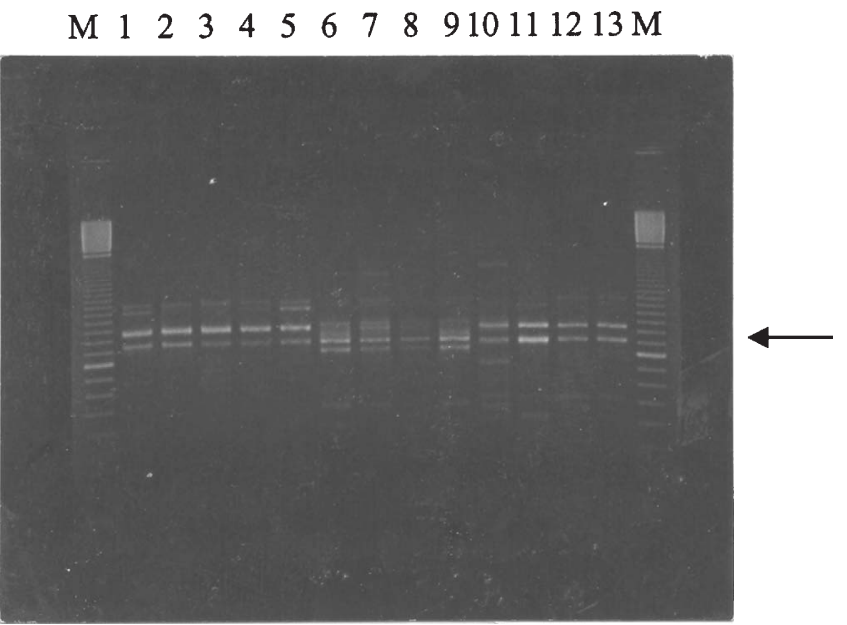

Fig. 5. RAPD profile generated by primer OPA20 with 13 samples of Sporobolus belonging to 3 species (sp, S. pyramidalis; sj, $S$. jacquemontii; and sf, $S$. fertilis). Lanes marked with $\mathrm{M}$ are $100 \mathrm{bp}$ molecular weight markers and lanes 1-13 are sp1, sp22, sp48, sp49, $\mathrm{sp} 55, \mathrm{sj} 87, \mathrm{sj} 114, \mathrm{sj} 116, \mathrm{sj} 135, \mathrm{sf} 25, \mathrm{sf140}, \mathrm{sf} 36, \mathrm{sf} 45$. Arrow indicates $S$. jacquemontii (850 bp)-specific marker ( $850 \mathrm{bp}$, lanes 6-9).

Three similarity coefficients were used to generate phenograms to aid in the visualisation of the genetic relationships among the 9 species of the $S$. indicus complex studied and the 3 Australian native species studied. The topology of the phenogram generated from the simple matching coefficient was found to be slightly different from that generated from the Dice (Fig. 6) and Jaccard's coefficients (Fig. 7). In the phenograms generated from the Dice and Jaccard's coefficients, all the species of the $S$. indicus complex were grouped into one major cluster and 
Table 4. Part of RAPD similarity matrix showing percentage genetic similarity and diversity among various species of the S. indicus complex

Data matrix being too large could not be presented

\begin{tabular}{|c|c|c|}
\hline $\begin{array}{l}\text { Comparison of one Sporobolus spp. } \\
\text { with another }\end{array}$ & $\begin{array}{c}\text { Genetic } \\
\text { similarity (\%) }\end{array}$ & $\begin{array}{c}\text { Genetic } \\
\text { diversity }(\%)\end{array}$ \\
\hline S. pyramidalis v. S. pyramidalis & $90-98$ & $2-10$ \\
\hline S. jacquemontii v. S. jacquemontii & $93-100$ & $0-7$ \\
\hline S. jacquemontii v. S. pyramidalis & $65-83$ & $17-35$ \\
\hline S. fertilis v. S. fertilis & $65-100$ & $0-35$ \\
\hline S. fertilis v. S. pyramidalis & $45-65$ & $35-55$ \\
\hline S. fertilis v. S. jacquemontii & $45-50$ & $50-55$ \\
\hline S. africanus v. S. africanus & $90-95$ & $5-10$ \\
\hline S. africanus v. S. pyramidalis & $43-58$ & $42-57$ \\
\hline S. africanus v. S. jacquemontii & $43-55$ & $45-57$ \\
\hline S. africanus v. S. fertilis & $70-83$ & $17-30$ \\
\hline S. natalensis v. S. natalensis & $54-93$ & $7-46$ \\
\hline S. natalensis v. S. pyramidalis & $65-85$ & $15-35$ \\
\hline S. natalensis v. S. jacquemontii & $53-68$ & $32-47$ \\
\hline S. natalensis v. S. fertilis & $48-65$ & $35-52$ \\
\hline S. natalensis v. S. africanus & $51-65$ & $35-49$ \\
\hline S. sessilis v. S. sessilis & $70-98$ & $2-30$ \\
\hline S. sessilis v. S. pyramidalis & $45-59$ & $41-55$ \\
\hline S. sessilis v. S. jacquemontii & $63-71$ & $29-37$ \\
\hline S. sessilis v. S. fertilis & $24-68$ & $32-76$ \\
\hline S. sessilis v. S. africanus & $29-73$ & $27-71$ \\
\hline S. sessilis v. S. natalensis & $47-68$ & $32-53$ \\
\hline S. elongatus v. S. elongatus & $75-84$ & $16-25$ \\
\hline S. elongatus v. S. pyramidalis & $40-56$ & $44-60$ \\
\hline S. elongatus v. S. jacquemontii & $50-69$ & $31-50$ \\
\hline S. elongatus v. S. fertilis & $41-65$ & $35-59$ \\
\hline S. elongatus v. S. africanus & $55-66$ & $34-45$ \\
\hline S. elongatus v. S. natalensis & $48-68$ & $32-52$ \\
\hline S. elongatus v. S. sessilis & $66-73$ & $27-34$ \\
\hline S. creber v. S. creber & $92-97$ & $3-8$ \\
\hline S. creber v. S. pyramidalis & $50-55$ & $45-50$ \\
\hline S. creber v. S. jacquemontii & $53-70$ & $30-47$ \\
\hline S. creber v. S. fertilis & $55-65$ & $35-45$ \\
\hline S. creber v. S. africanus & $60-68$ & $32-40$ \\
\hline S. creber v. S. natalensis & $48-73$ & $27-52$ \\
\hline S. creber v. S. sessilis & $65-77$ & $23-35$ \\
\hline S. creber v. S. elongatus & $73-90$ & $10-27$ \\
\hline S. laxus v. S. laxus & 90 & 10 \\
\hline S. laxus v. S. pyramidalis & $45-50$ & $50-55$ \\
\hline S. laxus v. S. jacquemontii & $58-65$ & $35-42$ \\
\hline S. laxus v. S. fertilis & $50-60$ & $40-50$ \\
\hline S. laxus v. S. africanus & $58-68$ & $32-42$ \\
\hline S. laxus v. S. natalensis & $48-65$ & $35-52$ \\
\hline S. laxus v. S. sessilis & $68-80$ & $20-32$ \\
\hline S. laxus v. S. elongatus & $73-84$ & $16-27$ \\
\hline S. laxus v. S. creber & $75-80$ & $20-25$ \\
\hline
\end{tabular}

the 3 Australian native species formed a second, distinct cluster. Species of the $S$. indicus complex were further divided into 3 subclusters (Figs 6 and 7).

\section{Discussion}

\section{RAPD markers for species identification}

Individual weedy species-specific markers were difficult to find for the 5 most serious weed species. For S. jacquemontii,
2 species-specific markers were found; however, only combined markers could be identified to separate the other 4 into 2 groups (viz. Group 1, S. pyramidalis and S. natalensis; Group 2, S. fertilis and S. africanus; Table 3). A possible reason for the lack of some species-specific markers was apparent in the results of the second study, which looked at the degree of genetic similarity among the species. It was found that only small genetic differences existed between $S$. pyramidalis and $S$. natalensis, and between $S$. fertilis and S. africanus (Figs 6 and 7, Table 4).

The molecular markers generated from this investigation can now be used to identify the 5 major weedy Sporobolus species of Australia provided all the reaction and cycling conditions of the RAPD technique are strictly maintained. Several factors (viz. template DNA concentration, magnesium concentration, primer annealing temperature, and primer base composition) affect the PCR reaction (Tingey et al. 1992). Furthermore, RAPD being a dominant marker system, several markers show a dominance/recessive inheritance pattern in diploid organisms. This results in a partial amplification of particular fragments and this makes identification of heterozygotes for the dominant allele difficult (Aman 1997). The resulting fragments may either be homozygous (AA) or heterozygous (Aa), and the absence of the fragment may indicate the underlying genotype (aa) (Weising et al. 1995). Therefore, a modified marker system, called the sequence characterised amplified regions (SCAR) markers (Paran and Michelmore 1993), has to be developed in order to convert the dominant weedy species-specific RAPD markers to codominant SCAR markers. The resultant specific PCR would create a robust diagnostic protocol for these weeds.

\section{Analysis of genetic diversity and relationships}

Genetic diversity studies at the molecular level have great implications for formulating weed management strategies, especially when there is taxonomic dispute regarding differentiating various species on a morphological basis (Lopez-Martinez et al. 1999). The present investigation has put forth the inter- and intra-specific genetic diversity and relationship among 9 member species of the $S$. indicus complex based on RAPD data. Among all 9 species, $S$. natalensis was found to be most genetically diverse (7-46\% genetic diversity) followed by $S$. fertilis $(0-35 \%$ genetic diversity) and S. sessilis (2-30\% genetic diversity). Although all the representative samples of the 3 introduced weedy species, giant rat's tail grasses ( $S$. pyramidalis, S. natalensis) and American rat's tail grass (S. jacquemontii), were from various places within Queensland, $S$. natalensis was found to be genetically more diverse (polymorphic) in comparison with the other 2 species (Table 4). In the case of Paramatta grasses, giant Parramatta grass $S$. fertilis was shown to be more diverse $(0-35 \%$ genetic diversity) in comparison with Parramatta grass S. africanus. One previous RAPD-based genetic diversity study on giant rat's 


\section{Dice Similarity Coefficient}

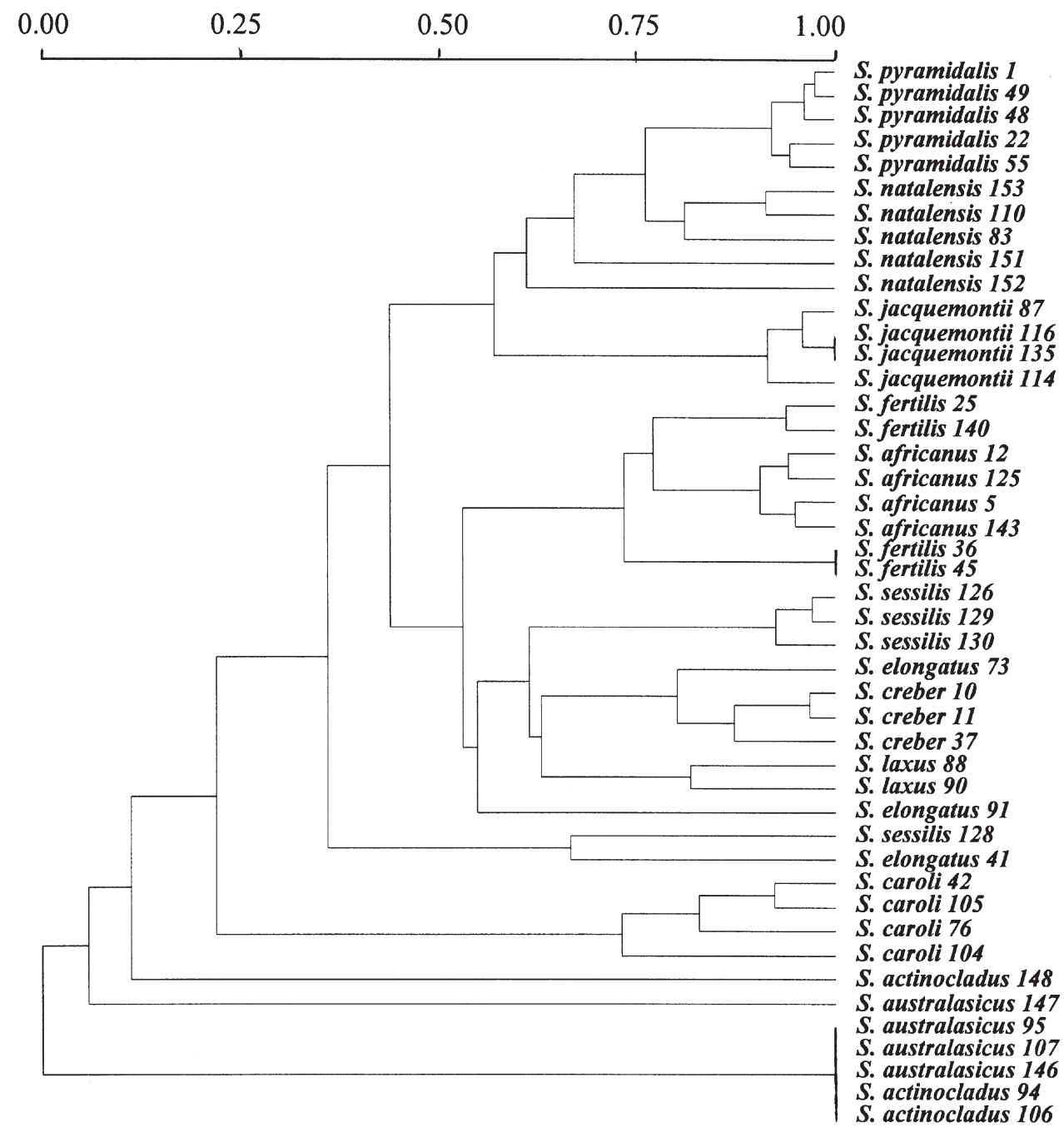

Fig. 6. A phenogram constructed for 45 samples taken from 12 Sporobolus species and created from the UPGMA cluster analysis using Dice's coefficient. All the species of the $S$. indicus complex formed one big cluster.

tail grasses had shown $S$. natalensis to be $16 \%$ dissimilar to S. pyramidalis, whereas there was only $8 \%$ diversity within S. pyramidalis (Hetherington 1997). This result is quite consistent with the present investigation where similarity between 2 giant rat's tail grasses ranged from 65 to $85 \%$ (i.e. $15-35 \%$ dissimilar), whereas similarity within S. pyramidalis individuals of this investigation was found to be $90-98 \%$ ( $2-10 \%$ dissimilar) (Table 4$)$.

The clustering pattern in the phenograms, using the 3 different similarity coefficients (Figs 6 and 7), was slightly different. Sporobolus pyramidalis, S. natalensis, and $S$. jacquemontii all clustered together in all 3 phenograms, forming a first subcluster. Similarly, giant Parramatta grasses and Parramatta grasses clustered together in all the phenograms. In phenograms generated from Dice and
Jaccard's coefficients, these formed the second subcluster. However, the phenogram generated using a simple matching coefficient separated the giant Parramatta grass and Parramatta grass group from the rest of the species under study (phenogram not shown). It has been pointed out that inclusion of data for absence of bands (e.g. in the analysis using the simple matching coefficient) from both individuals being compared reduces the level of similarity (Mace et al. 1999). Therefore, in the present context, phenograms generated from Dice and Jaccard's coefficients (Figs 1 and 2) have been considered more reliable in revealing the taxonomic relationship of various species of the $S$. indicus complex. This has been further substantiated by the fact that species of the complex formed a monophyletic clade in one phylogenetic study involving worldwide Sporobolus 


\section{Jaccard's similarity coefficient}

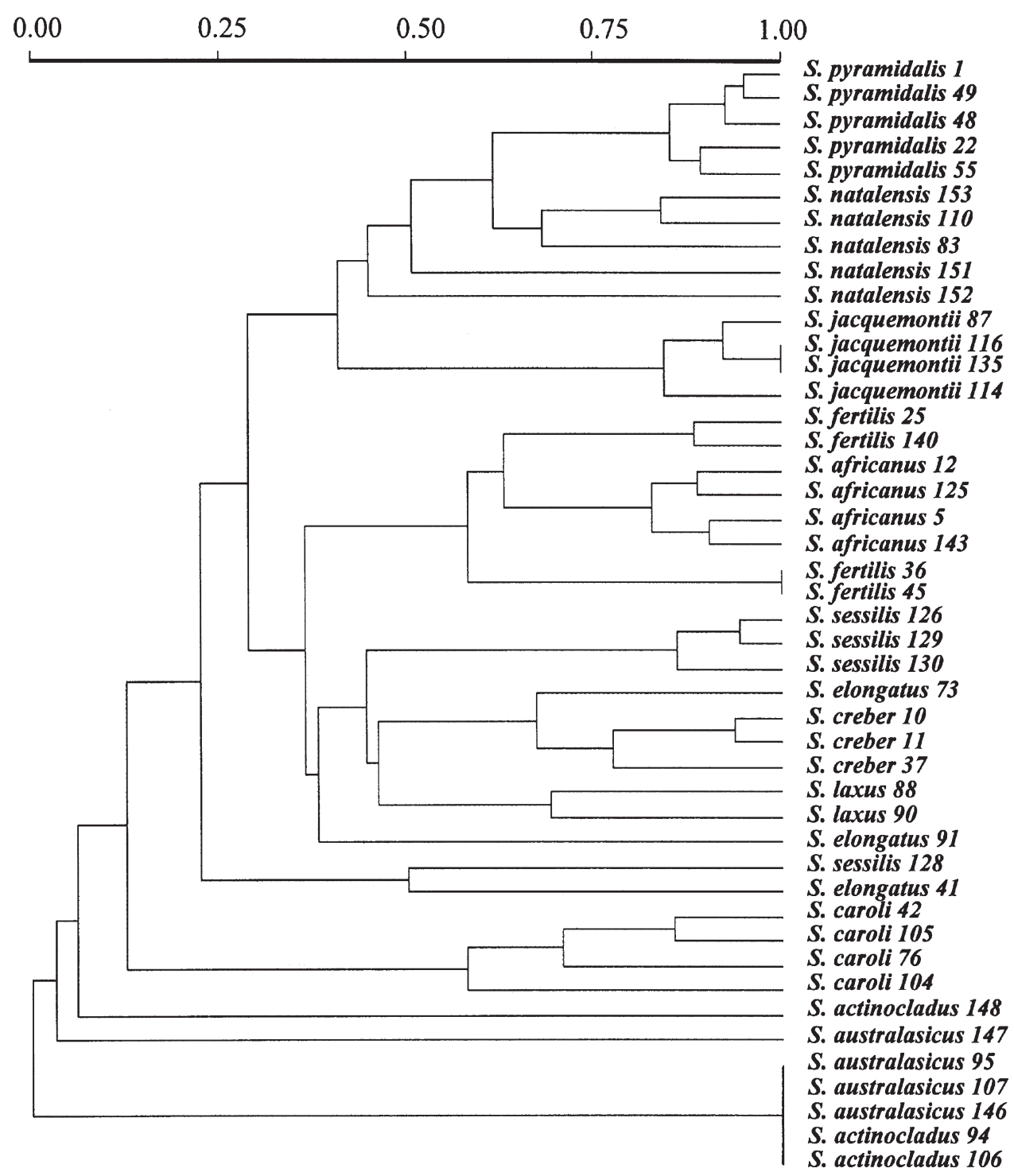

Fig. 7. A phenogram constructed for 45 samples taken from 12 Sporobolus species and created from the UPGMA cluster analysis using Jaccard's coefficient. All the species of the complex formed one big cluster.

species (Oritz-Diaz and Culham 2000) as well as in an earlier phylogenetic study based on internal transcribed spacers (ITS) sequences from our group (Shrestha et al. 2003). The 4 other, less problematic weedy species of the complex (viz. S. sessilis, S. elongatus, S. creber, and S. laxus), formed a third subcluster in various phenograms (Figs 6 and 7).

Clustering together of various species of the complex in the phenograms into 3 major clusters suggests the close relationship among the constituent species of each of these clusters (i.e. among S. pyramidalis, S. natalensis, and $S$. jacquemontii; S. fertilis and $S$. africanus; and S. sessilis, S. elongatus, S. creber, and S. laxus). The protein electrophoresis study of Vieritz (1993) also showed a close relationship among the $S$. pyramidalis, $S$. natalensis, and S. jacquemontii group and the S. elongatus, S. creber, S. laxus, and $S$. sessilis group.

A few differences in the way some individuals clustered were observed in the different phenograms. This may be attributed to one of a number of reasons. Firstly, as the RAPD-PCR searches the genome more widely, the observed variation then becomes greater due to the highly polymorphic DNA regions in those individuals. Secondly, as the RAPDPCR itself is not a very robust technique, the bands thus generated are not of the same intensity. This then creates difficulties when scoring for presence or absence of bands. Thirdly, the scored bands generated by 6 primers may not 
be sufficient for resolving various individuals clearly in the phenograms. Fourthly, the data matrix for analysis might have been very big. It has been mentioned that these clustering methods are sensitive to the number of operational taxonomic units (OTUs) in the various clusters, especially at high ranks (Sneath 1976).

The distinctness of the various species, and the taxonomic relationship among various weedy species of the complex, shown in this study, are similar to those previously generated using morphological and protein-based markers (Vieritz 1993; Simon 1996). As the present DNA-based studies are independent of environment and management practices (Morell et al. 1995), they offer a more reliable option for plant species-varieties-cultivars identification and genetic diversity analysis. The weedy species-specific RAPD fingerprints, as well as the genetic diversity and relationship analyses revealed in this present study, will be highly beneficial in formulating future weed-control strategies. This could either be achieved through positive identification (Joel et al. 1996) of these weeds in contaminated grass seed lots or aiding in the selection of appropriate herbicides for their control in pastures (Lopez-Martinez et al. 1999). Furthermore, this kind of knowledge may also be important to those who are attempting to introduce biological control agents to help to control these weeds (Nissen et al. 1995).

\section{Acknowledgments}

We thank B. K. Simon, Queensland Herbarium, for morphological identification of adult plants as well as for providing some of the Sporobolus seed samples used in this study. We extend our sincere thanks to S. Bray, J. Hilden, and all QDPI extension personnel who provided seed samples for the study. Our sincere thanks also go to Prof. W. Whaley, The University of New England, B. Worboys, Maitland City Council, and T. Schmitzer, NSW Agriculture, for providing further Sporobolus seed samples.

\section{References}

Aman RA (1997) A comparative assessment of molecular techniques employed in genetic diversity studies (and their suitability in resource-limited settings). In 'Molecular genetic techniques in plant genetic resources. Report of an International Plant Genetic Resources Institute (IPGRI) Workshop'. 9-11 October 1995, Rome, Italy. (Eds WG Ayad, T Hodgkin, A Jaradat, VR Rao) pp. 119-127. (IPGRI)

Anon. (1997) Giant rats tail grass Sporobolus pyramidalis and $S$. natalensis declared. Queensland Department of Primary Industries, Pest Facts Sheet, Produced by Land Protection Sub Program, Queensland.

Anon. (1999) Giant rats tail grass. Best practice manual. Information series QI99034, Compiled by the Giant Rats Tail Grass Project Team, Department of Primary Industries.

Betts J, Fenton G, Moore K (1990) Giant Parramatta grass control. Agnote, NSW Agriculture and Fisheries, NSW.

Dice LR (1945) Measures of the amount of ecologic association between species. Ecology 26, 297-302.
Edwards K, Johnstone C, Thompson C (1991) A simple and rapid method for the preparation of plant genomic DNA for PCR analysis. Nucleic Acids Research 19, 1349.

Golembiewski RC, Danneberger TK, Sweeney PM (1997) Potential RAPD markers for use in the identification of creeping bent grass cultivars. Crop Science 37, 212-214.

Graham GC, Henry RJ, Godwin ID, Nikles DG (1996) Phylogenetic position of Hoop pine (Araucaria cunninghamii). Australian Systematic Botany 9, 893-902.

Graham GC, Henry RJ, Redden RJ (1994) Identification of navy bean varieties using random amplification of polymorphic DNA. Australian Journal of Experimental Agriculture 34, 1173-1176.

Hetherington S (1997) Evaluation of endemic fungal pathogens as biological control agents of Sporobolus species. $\mathrm{PhD}$ thesis, The University of Queensland, Brisbane, Australia.

Jaccard P (1908) Nouvelles recherches sur la distribution florale. Bulletin. Societe Vaudoise Sciences Naturelles 44, 223-270.

Joel DM, Portnoy V, Katzir N (1996) Identification of single tiny seeds of Orobanche using RAPD analysis. Plant Molecular Biology Reporter 14, 243-248.

Laffan RA (1986) Parramatta grass (Sporobolus africanus) in the Coffs Harbour Agronomy district. In 'Parramatta grass and its control'. pp. 9-23. (NSW Department of Agriculture, Biological and Chemical Research Institute: Rydalmere, NSW)

Lopez-Martinez N, Salva AP, Finch RP, De Prado R (1999) Molecular markers indicate intraspecific variation in the control of Echinochloa spp. with quinclorac. Weed Science 47, 310-315.

Mace ES, Lester RN, Gebhardt CG (1999) AFLP analysis of genetic relationships among the cultivated eggplant, Solanum melongena L., and wild relatives (Solanaceae). Theoretical and Applied Genetics 99, 626-633. doi: 10.1007/S001220051277

Moodie M, Finch RP, Marshall G (1997) Analysis of genetic variation in wild mustard (Sinapsis arvensis) using molecular markers. Weed Science 45, 102-107.

Morell MK, Peakall R, Appels R, Preston LR, Lloyd HL (1995) DNA profiling techniques for plant variety identification. Australian Journal of Experimental Agriculture 35, 807-819.

Nei M, Li WH (1979) Mathematical model for studying genetic variation in terms of restriction endonucleases. Proceedings of the National Academy of Sciences of the USA 76, 5269-5273.

Nissen SJ, Masters RA, Lee DJ, Rowe ML (1995) DNA-based marker systems to determine genetic diversity of weedy species and their application to biocontrol. Weed Science 43, 504-513.

Oritz-Diaz J, Culham A (2000) Phylogenetic relationships of the genus Sporobolus (Poaceae: Eragrostideae) based on nr DNA ITS sequences. In 'Grasses: systematics and evolution'. (Eds SWL Jacobs, J Everett, A Jaradat, VR Rao) (CSIRO Publishing: Melbourne, Vic.)

Paran I, Michelmore RW (1993) Development of reliable PCR based markers linked to downy mildew resistance genes in lettuce. Theoretical and Applied Genetics 85, 985-993. doi: $10.1007 / \mathrm{BF} 00215038$

Shrestha S (2001) Molecular systematics of weedy Sporobolus species of Australia. PhD thesis, University of Queensland, Brisbane, Australia.

Shrestha S, Adkins SW, Graham GC, Loch DS (2003) Phylogeny of the Sporobolus indicus complex based on internal transcribed spacers (ITS) sequences. Australian Systematic Botany 16, 165-176. doi: $10.1071 / \mathrm{SB} 02009$

Simon BK (1993) Key to Australian grasses. 2nd edn. Queensland Department of Primary Industries Information Series, Q18901.

Simon BK (1996) Taxonomy of weedy rats tail grasses (Sporobolus spp.). In 'Proceedings of the Workshop Weedy Sporobolus Grasses, Current Knowledge and Future Directions.' Gympie. pp. 22-27. (Queensland Department of Primary Industries: Brisbane) 
Simon BK (1999) Taxonomy of the Sporobolus indicus complex. In 'Proceedings of the Workshop Weedy Sporobolus Grasses, Research Update'. Gympie. pp. 41-47. (Queensland Department of Primary Industries: Brisbane)

Simon BK, Jacobs SWL (1999) Revision of the genus Sporobolus (Poaceae, Chloridoideae) in Australia. Australian Systematic Botany 12, 375-448.

Sneath PHA (1976) Phenetic taxonomy at the species level and above. Taxon 25, 437-450.

Sneath PHA, Sokal RR (1973) 'Numerical taxonomy, the principles and practice of numerical classification.' (W. H. Freeman and Company: San Francisco, CA)

Sokal RR, Michener CD (1958) A statistical method for the evaluating systematic relationships. University of Kansas Science Bulletin 38, $1409-1438$.

Sokal RR, Sneath PHA (1963) 'Principles of numerical taxonomy.' (W. H. Freeman and Company: San Francisco, CA)
Tingey SV, Rafalski JA, Williams JGK (1992) Genetic analysis with RAPD markers. In 'Applications of RAPD technology to plant breeding'. Joint plant breeding symposia series. pp. 3-8. (Crop Science Society of America, American Society for Horticultural Science and American Genetic Association: Minneapolis, MN)

Vieritz AM (1993) Electrophoretic analysis of Sporobolus spp. by PAGE. Project Report 9.18 to Queensland Department of Primary Industries (QDPI).

Weising K, Nymbom H, Wolff K, Meyer W (1995) 'DNA fingerprinting in plants and fungi.' (CRC Press: Boca Raton, FL)

Welsh J, McClelland M (1990) Fingerprinting genomes using PCR with arbitrary primers. Nucleic Acids Research 18, 7213-7218.

Williams JGK, Kubelic AR, Livak KJ, Rafalski JA, Tingey SV (1990) DNA polymorphism amplified by arbitrary primers are useful as genetic markers. Nucleic Acids Research 18, 6531-6535.

Manuscript received 4 August 2004, accepted 13 December 2004 